David J. Garbary • Sarah J. Fraser •

Charlene Hubbard · Kwang Young Kim

\title{
Codium fragile: rhizomatous growth in the Zostera thief of eastern Canada
}

Received: 15 August 2003 / Revised: 11 February 2004 / Accepted: 18 February 2004 / Published online: 16 September 2004 (C) Springer-Verlag and AWI 2004

\begin{abstract}
A rhizomatous growth form of Codium fragile is described for the first time. Plants were collected in the Gulf of St. Lawrence in estuaries dominated by Zostera marina. Rhizomatous plants developed from propagules of whole plants that settled horizontally. Horizontal axes of C. fragile were up to $1 \mathrm{~m}$ long in plants collected in situ. Plants developed several to dozens of erect axes at right angle to the base. Horizontal growth of up to $0.2 \mathrm{~m}$ was found in field experiments where fragments were tied to plastic mesh and left in situ for 4 months. The unconsolidated filaments at the base of $C$. fragile often wrapped around the rhizomes of $Z$. marina and up to five separate attachment sites to eelgrass were found in single plants of C. fragile. In four estuaries, 57-100\% of Codium plants with identifiable substratum were attached to shoots and rhizomes of $Z$. marina. The rhizomatous growth form was found in plants identified as $C$. fragile ssp. tomentosoides (Nova Scotia and Prince Edward Island) and C. fragile ssp. atlanticum (Prince Edward Island), suggesting that this is a phenotypic response to growth in soft bottom environments.
\end{abstract}

Keywords Codium fragile - Eelgrass · Estuaries · Invasive algae $\cdot$ Zostera marina

Communicated by K Lüning

D. J. Garbary $(\bullet) \cdot$ S. J. Fraser · C. Hubbard

Department of Biology,

St. Francis Xavier University,

Antigonish, Nova Scotia, B2G 2W5, Canada

e-mail: dgarbary@stfx.ca

Tel.: +1-902-8672164

Fax: +1-902-8672389

K. Y. Kim

Department of Oceanography,

Chonnam National University,

500-757 Kwangju, Korea

\section{Introduction}

Codium fragile (Suringar) Hariot (hereafter Codium) is among the most widely distributed and invasive species of marine algae (Trowbridge 1998). There are six subspecies, of which three are considered invasive. Of these, only ssp. tomentosoides (van Goor) Silva has become a nuisance by achieving high biomass and outcompeting resident species on various spatial scales. In addition to the high biomass, the nuisance aspect of the species is associated with the ability of plants to attach to living shellfish (especially oysters) and then float them away on currents and tides. Hence the common name "oyster thief" (Wassman and Ramus 1973; see Trowbridge 1998 for other common names). On the rocky shores of eastern Canada where Codium is locally abundant, it develops the basic morphology reported from other regions. Thus, plants have a basal disk comprising numerous freely branching and interwoven filaments. This forms a dense mass that expands with plant growth. From the base arise several to many erect axes with typical morphology and anatomy (Hubbard and Garbary 2002).

After being introduced to northeastern North America in Long Island Sound in the 1950s, Codium spread north into the Gulf of Maine. Colonization in New England has been thoroughly documented (Mathieson et al. 2003). In eastern Canada, ssp. tomentosoides was first found in 1988 in Mahone Bay, south of Halifax on the Atlantic coast of Nova Scotia, where it was abundant on rock substrata in the subtidal zone (Bird et al. 1993). It was later reported in the southern Gulf of St. Lawrence from a soft-bottom habitat dominated by Zostera marina L. (hereafter Zostera or eelgrass) (Garbary et al. 1997). It is now known from a diversity of sites in New Brunswick, Prince Edward Island, and Nova Scotia where scattered drift plants have been found or established populations occur (Hubbard and Garbary 2002; Locke et al. 2002; Chapman et al. 2004). Schmidt and Scheibling (2003) also report the colonization of intertidal rock pools on the Atlantic coast of Nova Scotia. In addition to ssp. tomentosoides, a second morphological type that is consistent with ssp. atlanticum 
(Cotton) Silva was found in Malpeque Bay in Prince Edward Island (Hubbard and Garbary 2002).

Many sites in the Gulf of St. Lawrence where Codium is established are soft-bottomed estuaries dominated by swards of Zostera. Based on ecological observations in a Connecticut estuary, Malinowski and Ramus (1973) concluded that Zostera outcompetes Codium at high Zostera densities. Here, we show that Codium has morphological adaptations that allow it to compete with Zostera in healthy eelgrass beds.

The collapse of an eelgrass population was recently described from Antigonish Harbour in the southern Gulf of St. Lawrence (Seymour et al. 2002). Although the cause of this decline was not established, the impacts of the invasive green crab, Carcinus maenus L., were hypothesized as the source of the destruction. Codium is already having an effect on community structure in kelp bed habitats on the Atlantic coast of Nova Scotia (Chapman et al. 2004). Here we describe how Codium may also have a negative impact on Zostera and elucidate a new form of the species adapted for growth in softbottomed communities.

\section{Methods}

Fortnightly to monthly visits have been conducted to Caribou Harbour from April to October since 2001. In addition, general mapping surveys of Codium were conducted in 2001, 2002, and 2003 in Prince Edward Island and Nova Scotia. Populations were observed in situ in Nova Scotia (Caribou Harbour, $45^{\circ} 44^{\prime} 08^{\prime \prime} \mathrm{N}$, $62^{\circ} 39^{\prime} 29^{\prime \prime} \mathrm{W}$, Little Harbour, $45^{\circ} 39^{\prime} \mathrm{N}, 62^{\circ} 33^{\prime} \mathrm{W}$, and Chance Harbour, $45^{\circ} 40^{\prime} \mathrm{N}, 62^{\circ} 34^{\prime} \mathrm{W}$ ) and Prince Edward Island (Belmont Provincial Park, $46^{\circ} 32^{\prime} \mathrm{N} 63^{\circ} 51^{\prime} \mathrm{W}$ and March Water, $46^{\circ} 31^{\prime} \mathrm{N}$ $63^{\circ} 42^{\prime} \mathrm{W}$ ) during the summer of the three years. Like many estuaries in the southern Gulf of St. Lawrence, these sites have soft bottoms and are dominated by extensive beds of Zostera. Both drift Codium and thalli attached in situ were observed. At each site, the substratum for attachment was noted for 36-103 plants. Substrata included shells and rocks, eelgrass, other algae, and undetermined, i.e., thalli broken above the base or with no conspicuous substratum remaining.

A growth experiment was conducted in 2001 and 2002 in a sheltered cove in Caribou Harbour in which fragments of ssp. tomentosoides were excised from large plants and tied to stiff plastic netting with flagging tape (Fig. 1). The netting was staked at either end at $10-20 \mathrm{~cm}$ below the zero tide mark among Zostera plants. Two fragment types were used. In the first type, $20 \mathrm{~cm}$ long, unbranched fragments were laid horizontally, aligned in parallel at $10 \mathrm{~cm}$ intervals and tied to the netting at two places with flagging tape. In the second type, $20 \mathrm{~cm}$ long, $y$-shaped terminal portions of plants were fed through the netting from below and tied above the net. Growth was followed for 4 months.

In a laboratory tank experiment, sediment was collected from a Zostera bed, sieved through a $1 \mathrm{~cm}^{2}$ screen and placed in a fibreglass tank $(0.55 \times 2.0 \times 0.7 \mathrm{~m})$ to $2 \mathrm{~cm}$ depth. Twelve oven bricks $(3 \times 11.5 \times 23 \mathrm{~cm})$ were placed in the tank, with their upper surfaces raised slightly above the sediment. Bricks were soaked in seawater for $24 \mathrm{~h}$ prior to placement in the tank, and sediment surfaces comprised the remainder of the aquarium; half was not manipulated and half was seeded with living Zostera plants such that the rhizomes were just beneath the sediment surface, and the shoots were in the seawater column $(25 \mathrm{~cm})$.

Ten-centimetre-long apical branches $(n=24)$ of Codium from Caribou Harbour were placed such that they were: (1) horizontal on brick, (2) horizontal on mud, or (3) horizontal on mud but touching
Zostera rhizome. Six $10 \times 50 \mathrm{~cm}$ strips of plastic netting were placed in the same tank. Y-shaped Codium fragments $(n=45)$ were tied to the plastic in an upright position. Strips were placed so that the netting was flat on: (1) brick, or (2) sediment alone. The tank was maintained at ambient temperature $\left(\mathrm{ca} .15-20^{\circ} \mathrm{C}\right)$ and illuminated with cool-white fluorescent lamps at $40 \mu \mathrm{mol} \mathrm{m} \mathrm{m}^{-2} \mathrm{~s}^{-1}$ of photosynthetically active radiation. Seawater was circulated using two aeration pumps at one end of the tank. One half of the seawater was replaced in the tank each week, and observations were conducted over 4 months.

\section{Results}

In July 2003, ssp. tomentosoides was found in two new estuaries up to $15 \mathrm{~km}$ east of Caribou Harbour. At Little Harbour, plants were very abundant in the drift, with about one plant per $\mathrm{m}$ shoreline over a $0.5 \mathrm{~km}$ stretch of beach. At Chance Harbour, scattered plants were present in the Zostera bed, and a dense population was established on a mussel aquaculture line.

Field collections at Caribou Harbour had a strict seasonality for the production of propagules. Propagules were absent during April and early May but became abundant during late May and early June after which they ceased appearing in the drift. Propagules were $9.8 \pm 0.5 \mathrm{~cm}$ long (mean \pm SE, $n=55)$ and unbranched. Abscission zones occurred at the bases of branches of larger drift plants (Fig. 2), suggesting that the propagules developed from large overwintering thalli. By late June, the shallow subtidal eelgrass beds of Caribou Harbour had a Codium density of about one plant $4 \mathrm{~m}^{-2}$. Most plants were more than $20 \mathrm{~cm}$ tall and had produced many erect axes from an irregularly prostrate system. Throughout the summer, drift plants occurred at about 0.5 plant $\mathrm{m}^{-1}$ shoreline over a $1 \mathrm{~km}$ long beach. Plants declined in the shallow subtidal during late summer, and drift plants became rare by October.

Many Codium plants were apparently unattached, and consisted of a prostrate axis which formed numerous erect axes at right angles (Fig. 3). About two-thirds of the plants sampled from estuaries had this morphology. Erect axes were often very dense (Fig. 4). This growth form occurred in both ssp. tomentosoides and ssp. atlanticum. The basal system was up to $100 \mathrm{~cm}$ in length and generated several to more than 100 erect axes. The broken ends of some of these basal axes suggest that the plants developed from broken branches that came to lie horizontally on the substratum, or from the fragmentation of larger prostrate systems.

Codium plants attached to an identifiable substratum made up 10-60\% of thalli (Table 1) whether they were collected in the drift or in situ. When attached to hard substrata such as pebbles or shells, Codium formed a basal system typical of that in rocky substrata elsewhere, i.e., with a basal disk of interwoven filaments that do not form utricles. As plants grow, the basal disk expands outward to cover more of the substratum and generates additional erect axes. Even with similar basal morpholo- 
Fig. 1 Sample net for field experiment: all plants were initially $20 \mathrm{~cm}$ long and unbranched. Scale bar $20 \mathrm{~cm}$

Fig. 2 Fragmentation in process, with abscission zone present (arrows). Scale bar $1 \mathrm{~cm}$

Fig. 3 Rhizomatous growth with lateral branches at right angles to the main prostrate axes (arrows) of the plant. Scale bar $10 \mathrm{~cm}$

Fig. 4 Sample Codium regenerate at end of 4-month field experiment. Plant has a prostrate axis (arrows) and numerous erect laterals. Scale bar $5 \mathrm{~cm}$

Fig. 5 Large drift thallus with rhizomatous system and five sites of attachment (arrows) to Zostera rhizomes. Scale bar $10 \mathrm{~cm}$

Fig. 6 Portion of drift Codium with rhizomes and roots of Zostera (arrows) removed from substratum. $E$ Erect axis of thallus; $F$ filamentous growth of Codium entangling the Zostera rhizomes. Scale bar $2 \mathrm{~cm}$
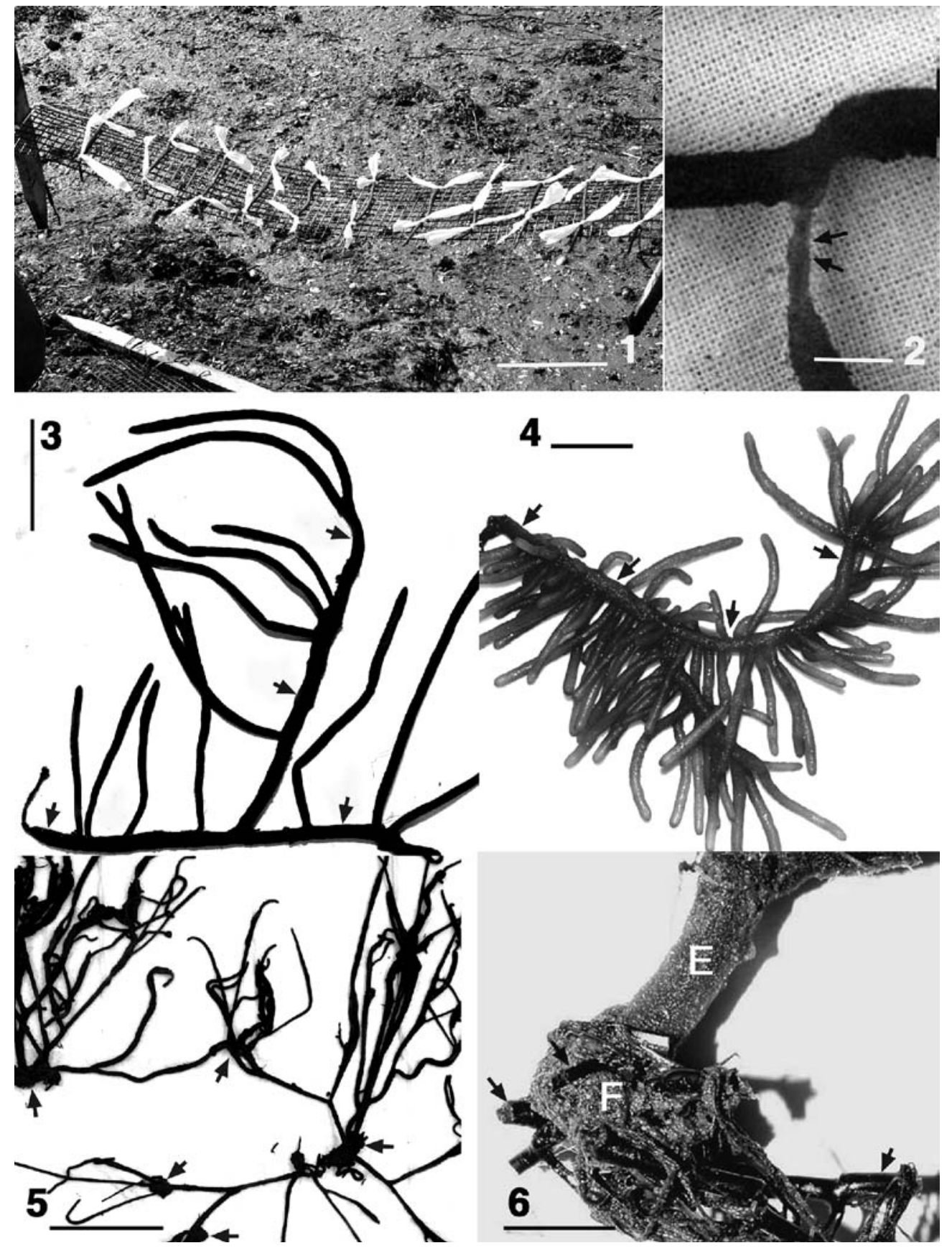

\begin{tabular}{|c|c|c|c|c|c|}
\hline \multirow[t]{2}{*}{ Site and date } & \multicolumn{2}{|c|}{ No basal system } & \multicolumn{2}{|c|}{ Basal system attachment } & \multirow[t]{2}{*}{$n$} \\
\hline & Unattached & Zostera & $\begin{array}{l}\text { Solid } \\
\text { (shells or stones) }\end{array}$ & Other algae & \\
\hline Caribou Harbour, April 2002 & $68 \%$ & $80 \%$ & $20 \%$ & - & 63 \\
\hline Caribou Harbour, Sept. 2002 & $41 \%$ & $100 \%$ & - & - & 42 \\
\hline Caribou Harbour, May 2003 & $54 \%$ & $92 \%$ & $8 \%$ & - & 36 \\
\hline Little Harbour, July 2003 & $52 \%$ & $72 \%$ & $25 \%$ & $3 \%$ & 75 \\
\hline Belmont, July -200 & $84 \%$ & $57 \%$ & $19 \%$ & $24 \%$ & 103 \\
\hline March Water, July 2002 & $91 \%$ & $89 \%$ & $11 \%$ & - & 103 \\
\hline
\end{tabular}

Table 1 Percent frequency of substrata of Codium thalli in soft-bottomed habitats in the Gulf of St. Lawrence in Nova Scotia (Caribou Harbour) and Prince Edward Island (Belmont and March Water)

.


gy, the basal filaments in estuarine populations are more loosely interwoven relative to plants from rocky habitats.

The most common attachment of prostrate axes was to rhizomes of Z. marina, where the prostrate axes often produced unconsolidated filaments that surrounded the rhizome or shoot base (Table 1). In other cases, the rhizome was incorporated into the growing axis of the Codium. The prostrate Codium axes were commonly attached at multiple sites (maximum of five places) to different Zostera rhizome segments (Fig. 5). Large plants with an extensive prostrate branching system up to $1 \mathrm{~m}$ long were also present. When Zostera shoots were associated with Codium, the base of the Codium surrounded the shoot base and some of the rhizome. Contact of Codium with Zostera rhizomes varied from a tenuous connection of a few loose filaments to continuous envelopment of up to several centimetres (Fig. 6).

\section{Field experiment}

Experimental manipulation of Codium in situ replicated many of the morphological features described above. Prostrate, unbranched axes continued to grow horizontally and within the 4 months elongated by over $10 \mathrm{~cm}$ in both 2001 and 2002 (Fig. 7). In 2002, these fragments produced a mean of 30 lateral branches per thallus (Fig. 8) and the longest branches grew to a mean of about $12 \mathrm{~cm}$ (Fig. 9). By the end of the experimental period, every thallus had formed at least one lateral, and a maximum of 128 laterals had developed.

The dichotomizing branches that were oriented vertically on the nets showed high loss. The remaining plants continued to grow vertically, forming up to four dichotomies. Several of these regenerates produced horizontal axes that grew along the sediment and developed up to $3 \mathrm{~cm}$ over the experimental period.

\section{Laboratory experiment}

Regeneration of Codium in the laboratory mimicked the situation in the field. Ten-centimetre-long, unbranched segments placed on the bricks grew slightly in length over the 4-month period $(2.5 \pm 0.5 \mathrm{~cm}$, mean $\pm \mathrm{SE})$. They formed filamentous masses that resembled basal discs, and attached to the bricks. Fragments on soft substratum continued to grow horizontally $(2.0 \pm 0.4 \mathrm{~cm}, \mathrm{mean} \pm \mathrm{SE})$ and only produced non-utricle forming filaments when axes were in contact with a hard substratum.

Codium fragments held vertically by attachment to netting and regenerated a basal disc on the brick substratum but tended to form a prostrate axis on sediment, regardless of whether or not the Zostera rhizome was in the sediment. About half of the fragments in the tank formed filamentous projections of at least $1 \mathrm{~cm}$. In several cases, these filaments intertwined with Zostera rhizomes and shoots. Growth was slower in the tanks relative to the field, and there was a $90 \%$ Zostera mortality after 4 months.
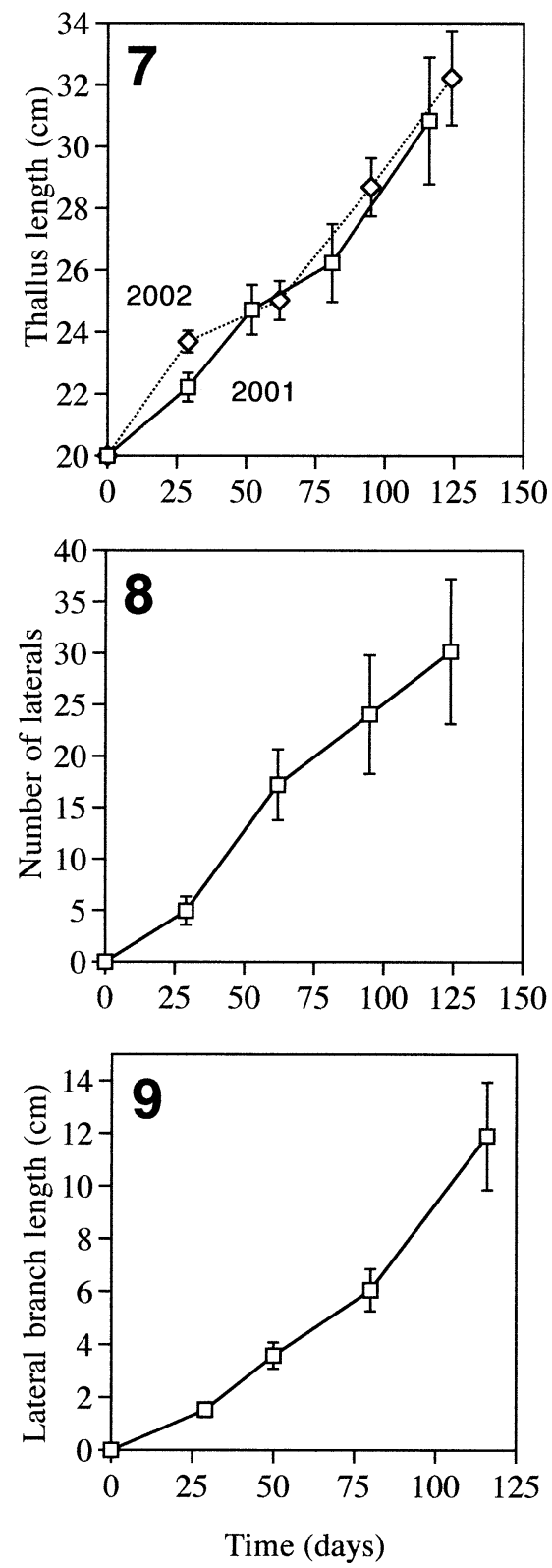

Fig. 7 Rhizomatous growth from June to September in 2001 and 2002. Only fragments that increased in length are included. Mean \pm SE, $n=60$

Fig. 8 Development of upright laterals from June to September 2002. Mean \pm SE, $n=60$. All plants were initially unbranched

Fig. 9 Length of longest lateral branches on each regenerating fragment. Mean \pm SE, $n=60$

\section{Discussion}

In the Gulf of St. Lawrence, vegetative propagation of Codium is a regular event, occurring at the end of May and in early June. Timing of propagation is a localized event, varying with region (Trowbridge 1998). Fralick and Mathieson (1972) report fragmentation of Codium from January to March in New England. We observed this process as a spring phenomenon, similar to Codium in 
Oregon (Trowbridge 1993). Fragmentation is an important reproductive strategy for coenocytic green algae, and this mode of asexual reproduction has been used to account for their rapid dissemination (Borden and Stein 1969; Ceccherelli and Cinelli 1999; Smith and Walters 1999).

Codium was first discovered in Caribou Harbour in 1996 (Garbary et al. 1997). Although Codium is known for its ability to spread rapidly (Carlton and Scanlon 1985), after 8 years at this site we have only recently (July 2003) found Codium at two other sites, less than $15 \mathrm{~km}$ away from Caribou Harbour. Thus Codium in this region does not seem to be spreading as rapidly as it has in other, more southern locations. Despite a favourable current in the Northumberland Strait, Codium has not appeared in Merigomish Harbour, a jump of an additional $5 \mathrm{~km}$. It is difficult to reconcile the apparent abundance of Codium at three sites (especially drift plants) and the time lag in colonizing an adjacent, highly suitable estuary.

Codium is generally considered a plant of hard substrata, varying from solid bedrock to smaller rocks, pebbles, and both living and dead shells of various molluscs (Trowbridge 1998). Even when growing in habitats dominated by soft bottoms, a common substratum noted for growth were the shells of molluscs, including oysters. Rapid growth and photosynthesis make plants sufficiently buoyant to remove the animals from the bottom and float them away with the current (Wassman and Ramus 1973; Loosanoff 1975; Droomgoole 1982).

Codium is a nuisance organism, and is often responsible for fouling boats and aquaculture operations (Carlton and Scanlon 1985; Trowbridge 1998). The Codium population observed at Chance Harbour was extremely dense on the mussel lines, covering about $80 \%$ of available rope space. Bird et al. (1993) describe the fouling of aquaculture apparatus as "one of the most significant adverse affects of this species." Chapman et al. (2004) report negative impacts of Codium in kelp communities on the Atlantic coast of Nova Scotia. In addition, Scheibling and Anthony (2001) report negative impacts on the sea urchin Strongylocentrotus droebachiensis when fed a diet of Codium.

The damaging effects of Codium are not limited to marine animals. Here, we report the ability of $C$. fragile to attach and remove shoots and rhizomes of $Z$. marina from the substratum, and thus propose a new nickname: 'eelgrass thief.' This form of attachment may help explain the ability of $C$. fragile to become abundant in soft-bottom communities in the eelgrass meadows in the southern Gulf of St. Lawrence. Attaching to shoots and rhizomes provides sufficient anchoring that plants can grow and reproduce before accumulating in the drift.

Malinowski and Ramus (1973) concluded that Codium can be excluded at high Zostera densities in a Connecticut estuary. They argued that eelgrass outcompetes Codium. This is not the situation in eastern Canada, where Codium can become a prominant species in eelgrass beds. In addition, Codium also utilizes the eelgrass as a primary substratum for attachment and can physically uproot the shoots and rhizomes. Large Codium populations have persisted in Caribou Harbour for at least 6 years. Hence, the competitive interactions of these species appear different in estuaries in the Gulf of St. Lawrence and in New England.

The rhizomatous growth form may be an adaptation for nutrient absorption. The proximity of the prostate axes to the sediment may lead to nutrient uptake directly from sediment, in addition to nutrients from the water column. This was reported for the rhizomatous coenocyte, Caulerpa cupressoides (West) C. Agardh (Williams 1984; Williams and Fisher 1985).

Seymour et al. (2002) documented a $95 \%$ decline of Zostera in Antigonish Harbour, and noted ca.50\% declines in two migrating bird species that either feed on the rhizomes and roots (Canada geese) or feed on invertebrate populations in eelgrass beds (common goldeneye). The cause of the eelgrass decline was not determined; however, there was no evidence of eelgrass wasting disease or anthropogenic eutrophication. The decline may have been associated with foraging activity of the invasive green crab, Carcinus maenus, the presence of which is correlated with reduced abundance of Zostera (Locke et al. 2002). Codium has not yet colonized Antigonish Harbour, and cannot be responsible for the decline. In soft-bottom Zostera beds where Codium has become abundant, this may be an additional cause of Zostera mortality. If green crabs are the basis of large-scale mortality of Zostera in eastern Canada, then this will be exacerbated in sites where Codium also colonizes.

Acknowledgements We thank Mary Jamieson, Carrie Ferguson, Ray McCarthy, Shawn McDonald, Zachary Mills, Jonathan Bennett, and Katie Fraser for assistance in the field. We also thank Paul Budreski for providing boat access to Chance Harbour. This project was funded by the University Council for Research of St. Francis Xavier University, a discovery grant from the Natural Sciences and Engineering Research Council of Canada (NSERC) to D.J.G., an undergraduate NSERC award to S.J.F., and a Korea Research Foundation Grant (KRF-2002-070-C00088) to K.Y.K. All experiments comply with the appropriate Canadian legislation.

\section{References}

Bird CJ, Dadswell MJ, Grund DW (1993) First record of the potential nuisance alga Codium fragile ssp. tomentosoides (Chlorophyta, Caulerpales) in Atlantic Canada. Proc Nova Scotia Inst Sci 40:11-17

Borden CA, Stein JR (1969) Reproduction and early development in Codium fragile (Suringar) Hariot: Chlorophyceae. Phycologia 8:91-99

Carlton JT, Scanlon JA (1985) Progression and dispersal of an introduced alga: Codium fragile ssp. tomentosoides (Chlorophyta) on the Atlantic coast of North America. Bot Mar 28:155-165

Ceccherelli G, Cinelli F (1999) The role of vegetative fragmentation in dispersal of the invasive alga Caulerpa taxifolia in the Mediterranean. Mar Ecol Prog Ser 182:299-303

Chapman AS, Scheibling RE, Chapman ARO (2004) Species introductions and changes in marine vegetation of Atlantic Canada. In: Claudi R (ed) Alien invasive species: threat to Canadian biodiversity. Natural Resources Canada, Ottawa (in press) 
Dromgoole FI (1982) The buoyant properties of Codium. Bot Mar 25:391-397

Fralick RA, Mathieson AC (1972) Winter fragmentation of Codium fragile (Suringar) Hariot ssp. tomentosoides (van Goor) Silva (Chlorophyceae, Siphonales) in New England. Phycologia 11:67-70

Garbary DJ, Vandermeulen H, Kim KY (1997) Codium fragile ssp. tomentosoides (Chlorophyta) invades the Gulf of St. Lawrence, Atlantic Canada. Bot Mar 40:537-540

Hubbard CB, Garbary DJ (2002) Morphological variation of Codium fragile (Chlorophyta) in eastern Canada. Bot Mar 45:476-485

Locke A, Hanson JM, Ellis KM, Klassen GJ, Garbary DJ, MacNair NG (2002) Effects of recent invasions on ecosystems in the southern gulf of St. Lawrence: predictions and early observations. In: Proceedings of the 11th International Invasive Species Conference, 25-28 February 2002, Alexandria, Canada, pp 143-153

Loosanoff VL (1975) Introduction of Codium in New England waters. Fish Bull 73:215-218

Malinowski KC, Ramus J (1973) Growth of the green alga Codium fragile in a Connecticut estuary. J Phycol 9:102-110

Mathieson AC, Dawes CJ, Harris LG, Hehre EJ (2003) Expansion of the Asiatic green alga Codium fragile ssp.tomentosoides in the Gulf of Maine. Rhodora 105:1-53

Scheibling RE, Anthony SX (2001) Feeding, growth and reproduction of sea urchins (Strongylocentrotus droebachiensis) on single and mixed diets of kelp (Laminaria spp.) and the inva- sive alga Codium fragile ssp. tomentosoides. Mar Biol 139:139-146

Schmidt AL, Scheibling RE (2003) Density, recruitment, growth, and survival of the invasive green alga Codium fragile ssp. tomentosoides in tidepools on a rocky shore in Nova Scotia. Abstract Book, Plant Canada 2003, 25-29 June 2003, St. Francis Xavier University, Antigonish, Nova Scotia, p 33

Seymour NR, Miller AG, Garbary DJ (2002) Decline of Canada geese (Branta canadensis) and common goldeneye (Bucephala clangula) associated with collapse of eelgrass (Zostera marina) in a Nova Scotia estuary. Helgol Mar Res 56:198-202

Smith CM, Walters LJ (1999) Fragmentation as a strategy for Caulerpa species: fates of fragments and implications for management of an invasive weed. Mar Ecol 20:307-319

Trowbridge CD (1993) Interactions between an ascoglossan sea slug and its green algal host: branch loss and role of epiphytes. Mar Ecol Prog Ser 101:263-273

Trowbridge CD (1998) Ecology of the green macroalga Codium fragile (Suringar) Hariot 1889: invasive and non-invasive subspecies. Annu Rev Oceanogr Mar Biol 36:1-64

Wassman R, Ramus J (1973) Seaweed invasion. Nat Hist 82:24-36

Williams SL (1984) The uptake of sediment ammonium and translocation in the marine green macroalga Caulerpa cupressoides. Limnol Oceanogr 29:374-379

Williams SL, Fisher TR (1985) Kinetics of the nitrogen-15 labeled ammonium uptake by Caulerpa cupressoides (Chlorophyta). J Phycol 21:287-296 